\title{
INVESTIGATIONS ON THE ROOT OF MANIHOT UTILISSIMA POHL
}

\author{
(PROGRESS REPORT)
}

By H. E. Cruz Monclova Ch. E.

Agricultural Experiment Station, Río Piedras, P. R.

The work appearing now, is the incomplete result of experiments undertaken in cooperation by the Divisions of Agronomy and Industrial Chemistry, of the Agricultural Experiment Station, on the cassava plant. The complete and final results will appear as soon as they are available.

\section{Methods of ANaLysis}

1. Determination of Hydrocyanic Acid.

The principal aims of the determination of hydrocyanic acid in the cassava root were two:

First.-To compare the hydrocyanic acid content of the varieties of cassava roots under study.

Second.-To find out if possible the hydrocyanic acid content of the cassava roots at different stages of their growth.

After several methods of analysis were tried finally Liebig's Method was selected and adapted to the cassava, as the easier and more accurate.

One hundred grams of sample are weighed and placed in a twoliter flask; together with 1 of liter distilled water and 20 ce. of $\mathrm{H}_{2} \mathrm{SO}_{4}$ of known specific gravity are added and the flask is connected to a condenser. The distillate is collected in a 500 ec. volumetric flask, into which have been placed 25 ce. of dilute $\mathrm{NaOH}$ solution. At least $500 \mathrm{cc}$. of the distillate should be collected to ensure that all the $\mathrm{HCN}$ in the sample is distilled off. After the distillation is finished an aliquot part is taken and titrated with $-{ }_{100}^{\mathrm{N}} \quad \mathrm{AgNO}_{3}$. The residue in the flask is saved for the determination of starch and of fiber.

Some trial distillations were made in order to establish the least possible volume of the distillate to be collected for titration. By taking two consecutive portions of distillate of 250 ce. each, and titrating an aliquot of $50 \mathrm{cc}$. of each separately, it was found that not all the HCN in the sample was collected in the first 250 ce. of dis- 
tillate passing over, but that there was yet a perceptible amount in the next 250 ce. portion of distillate obtained as shown by the following results:

\begin{tabular}{|c|c|c|c|}
\hline & Variety of Cassava & 1st. Portion & 2nd. Portion \\
\hline $\begin{array}{l}\text { Carlos Ch } \\
\text { Negrona } \\
\text { Manuel P }\end{array}$ & 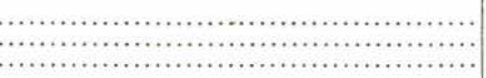 & $\begin{array}{l}2.9 \mathrm{cc} . \\
3.2 \mathrm{cc} . \\
2.7 \mathrm{cc} .\end{array}$ & $\begin{array}{l}0.8 \mathrm{cc} . \\
0.6 \mathrm{cc} . \\
0.4 \mathrm{cc} .\end{array}$ \\
\hline
\end{tabular}

On using $\frac{\mathrm{N}}{10}$ solution of $\mathrm{AgNO}_{3}$ for the titration it was found that it did not afford the most accurate results obtainable under the circumstances. Comparative results are shown below for titrations made with $\frac{\mathrm{N}}{10}$ and $\frac{\mathrm{N}}{100}$ solutions of $\mathrm{AgNO}_{3}$.

\begin{tabular}{|c|c|c|}
\hline Cassava Variety & $\frac{\mathrm{N}}{10} \mathrm{AgNO}_{3}$ & $\frac{\mathrm{N}}{100} \mathrm{AgNO}$, \\
\hline 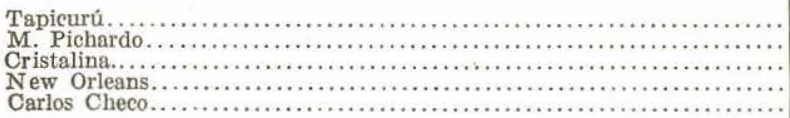 & $\begin{array}{l}0.40 \mathrm{cc} . \\
0.20 \mathrm{cc} \\
0.20 \mathrm{cc} \\
0.10 \mathrm{cc} . \\
0.15 \mathrm{ce}\end{array}$ & $\begin{array}{l}3.4 \mathrm{cc} . \\
1.6 \mathrm{cc} . \\
1.9 \mathrm{cc} \\
1.0 \mathrm{cc} . \\
1.5 \mathrm{cc} .\end{array}$ \\
\hline
\end{tabular}

Determination of Starch and Fiber

The residue from the distillation of the HCN contains in the solution all the starch present in the sample. It has been transformed into dextrose by boiling with the acid. Besides, this residue contains also the fiber of the sample.

The residue is brought to volume of 1 liter at $20^{\circ} \mathrm{C}$ and filtered. The specific gravity of the filtrate is determined at $20^{\circ} \mathrm{C}$ by means of pyenometer. From the specific gravity of the liquid, the starch can be calculated by means of a curve made beforehand, for pure dextrose, and taking into consideration all the factors affecting the results. The fiber is obtained after filtering all the liquid; it is washed carefully and then transferred to a tared crucible, and dried at $100^{\circ} \mathrm{C}$. 


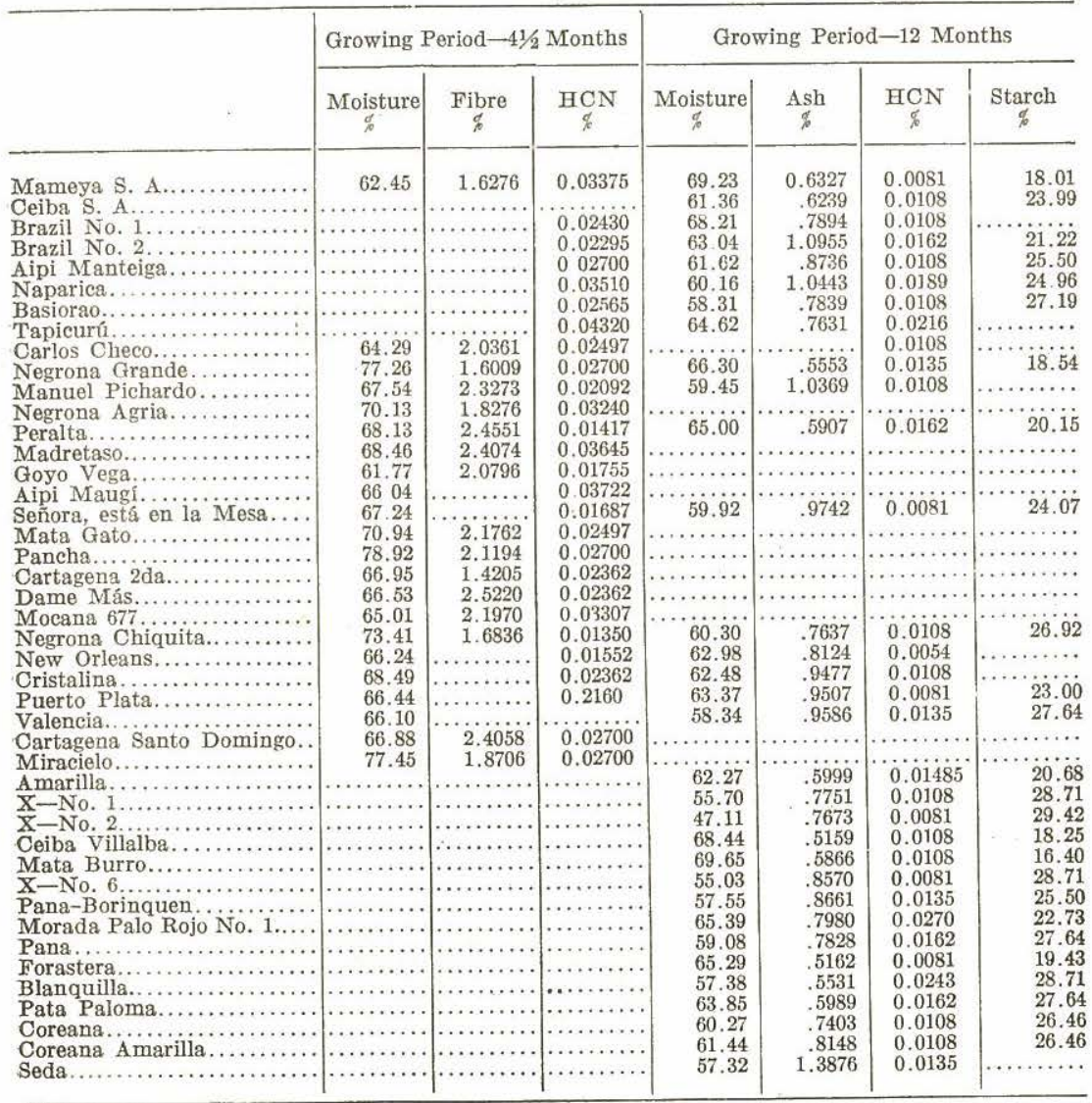

\section{Description of the Roots of Cassava Varieties}

The ideal root of cassava for industrial purposes, either for starch or flour making must possess a number of characteristics all contributing to a cheaper or better final product. The cassava root must have the proper chemical composition-high starch and protein content, low humidity, low fibre content. The rind must be thin; its color must be white. The peel or skin must be thin, smooth, easily detached and of very light color. The inside of the root must be low in coloring matter and when pulped must be easily washed; when dried it must remain white, with no extraneous coloring; it must yield flour or starch of pure-white color.

In no one variety of cassava do we find together all these characteristics. But we believe that by selection and breeding there can 
be obtained a type that will be much nearer the ideal than the presently known varieties of cassava.

The ratio of length of root to diameter must be small as a relatively short and thick root is easier to handle in the plant than a long and light root.

We are giving here some of the characteristics of some of the varieties studied, grouped according to color, type and thickness of the skin, underskin, rind and pulp.

I. Varieties with White under-skin.

1. Mameya, S. A.

The skin is thin and rough of dark brown color, underskin white. The rind is medium thick. The pulp is white.

2. Ceiba, San Antonio.

The skin is very thin and rather smooth; and of brown color. Underskin is white. The rind is thin. Pulp is yellowish-white.

3. Brazil No. 1.

The skin is thick and rough of dark brown color. Underskin is white the rind is medium thick. The pulp is white.

4. Brazil No. 2.

The skin is thick and rough and of dark brown color. Underskin is white. The rind is medium thick. The pulp is white.

5. Aipi Manteiga.

The skin is thin and rough of very dark brown color. Underskin white. The rind is thick. The pulp is white.

6. Tapicurú.

The skin is thick and of dark brown color; underskin is white. The rind is thick. The pulp is white.

7. Negrona Agria.

The skin is thick, rough and dark brown. Underskin is white. The rind is very thick. The pulp is white.

8. Cartagena 2da.

Skin is thick, very rough and dark brown. Underskin is white. The rind is thin. The pulp is white.

9. Cartagena Sto. Domingo.

Skin is thin, smooth and of straw color. Underskin white. The rind is thin. Pulp is white. 
II. Varieties with light-red Underskin.

10. Manuel Pichardo.

The skin is thin and smooth of light straw color. Underskin lightred color. The rind is thick. Pulp is white.

11. Peralta.

The skin is thin and smooth, light straw color. Underskin lightred color. The rind is thick. Pulp is white.

12. Machetazo.

The skin is thin, medium rough and brown. Underskin is lightred color. The rind is thin. Pulp is yellowish.

13. Señora está en la Mesa.

The skin is thick, rough and dark brown. Underskin is lightred color. The rind is thin. Pulp is white.

14. Dame Más.

The skin is thick, rough and dark brown. Underskin light-red color. The rind is thick. Pulp is white.

15. Mocana 677.

The skin is thick, smooth and dark brown. Underskin is lightred color. The rind is thin. The pulp is white.

16. Negrona Chiquita.

The skin is thick, medium smooth and dark brown. Underskin is light-red color. The rind is thick. The pulp is white.

17. New Orleans.

The skin is very thin, smooth, and of light straw color. Underskin is light-red color. The rind is thin. The pulp is white.

18. Cristalina.

The skin is very thin, very smooth and of light straw color. The underskin is light-red color. The rind is thin. The pulp is white.

19. Puerto Plata.

The skin is thin, smooth and of light straw color. The underskin is light-red color. The rind is of medium thickness. The pulp is white.

III. Varieties having Red Underskin.

20. Miracielo.

The skin is thick, rough and of dark brown color. The underskin is red in color. The rind is thin. The pulp is white.

21. Valencia.

The skin is thick, rough and of very dark brown color; underskin red in color. The rind is thick. The pulp is white. 


\section{Aipi Mangi.}

The skin is thick, rough and of dark brown color. The underskin is red in color. The rind is thin. The pulp is white.

23. Goyo Vega.

The skin is thick, rough and dark brown color. The underskin is red in color. The rind is thick. The pulp is white.

24. Negrona Grande.

The skin is thick, rough and dark brown color. The underskin is red in color. The rind is thick. The pulp is white.

25. Carlos Checo.

The skin is thick, rough and dark brown in color. Underskin is red in color. The rind is thick. The pulp is white.

The results given in this preliminary paper are not final nor complete. Much more work has to be done yet to have the complete chemical and industrial data on the root of the cassava. From the data gathered, however incomplete, certain conclusions can be derived, especially those referring to moisture content and to hydrocyanic acid content. It appears that the water content of the root decreases with its age; obeying the same variation as the hydrocyanic acid content. These variations in general are not of the same degree for different varieties.

\section{BIBLIOGRAPHY}

1. Scott-Standard Methods of Chemical Analysis.

2. de Gody-Estudio Agricola Industrial da Mandioca. Piracicaba 1921.

3. A Markus-Maniok, Manihot Utilissima, Pohl. Der Tropenpflanzer-No. 4, 1935. p. 144. 